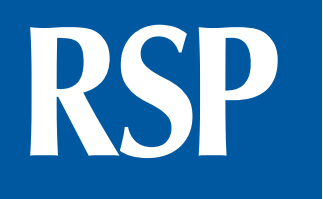

http://www.rsp.fsp.usp.br/
Revista de Saúde Pública

\title{
Resilience and mental health problems in children and adolescents who have been victims of violence
}

\author{
Natália Amaral Hildebrand' (iD, Eloisa Helena Rubello Valler Celeri" (iD, André Moreno \\ Morcillo"I' (ID), Maria de Lurdes Zanolli"' (iD \\ I Universidade Estadual de Campinas. Faculdade de Ciências Médicas. Programa de Pós-Graduação em Saúde \\ da Criança e do Adolescente. Campinas, SP, Brasil \\ " Universidade Estadual de Campinas. Faculdade de Ciências Médicas. Departamento de Psicologia Médica e \\ Psiquiatria. Campinas, SP, Brasil \\ III Universidade Estadual de Campinas. Faculdade de Ciências Médicas. Departamento de Pediatria. Campinas, \\ SP, Brasil
}

\section{ABSTRACT}

OBJECTIVE: To understand the process of resilience (social support and resources of the family environment) and the chance of mental health problems in children and adolescents (9-16 years) who have been victims of domestic violence, assisted in specialized services (Group 1 - G1) and in school services without reports of domestic violence (Group 2 - G2).

METHODS: Various semi-structured instruments were applied to the pairs (guardian and child or adolescent): the Strengths and Difficulties Questionnaire (SDQ); the Resiliency Scales for Children and Adolescents (RSCA), including Scale I (SI - sense of control), Scale II (SII relationship skills) and Scale III (SIII - emotional reactivity); the Social Support Appraisals; the Home Environment Resources Scale and a questionnaire created by the authors to characterize the population.

Correspondence:

Natália Amaral Hildebrand

Rua Dr. Jorge Antônio José, 165 Residencial Terras do Barão, Barão Geraldo

13085-632 Campinas, SP, Brasil

E-mail: nataliaah@gmail.com

Received: Aug 2, 2017

Approved: Apr 5, 2018

How to cite: Hildebrand NA Celeri EHRV, Morcillo AM, Zanolli ML. Resilience and mental health problems in children and adolescents who have been victims of violence. Rev Saude Publica. 2019;53:17.

Copyright: This is an open-access article distributed under the terms of the Creative Commons Attribution License, which permits unrestricted use, distribution, and reproduction in any medium, provided that the original author and source are credited.
RESULTS: There was no difference in the prevalence of resilience between G1 and G2. Children and adolescents of both groups had a higher chance of low resilience in the absence of perception of social support from the teacher (SI; SIII) and other people in the community (SI; SII). Girls had higher chance of low resilience (SIII). The establishment of routine or rules in the lives of the children and adolescents facilitated the development of resilience (SIII). In G1, the prevalence of mental health problems was $65 \%$ for the self-application version of the SDQ for children and adolescents (SDQ/CA) and 54\% for the version answered by the guardians (SDQ/G). In G2, it was 33\% for SDQ/CA and 37.9\% for SDQ/G. Domestic violence against children and adolescents was a risk factor for the development of mental disorders (SDQ/G). Subjects with low resilience (SI) had a higher chance of developing mental health problems (SDQ/CA). Despite originating from the same regions, the groups had socioeconomic differences, which showed no relationship with resilience.

CONCLUSIONS: The quality and perception of social support and resources present in the home environment may have facilitated the development of resilience in the studied children and adolescents. Violence may have increased the chance of mental health problems, domestic violence being an aggravating factor. There is need for research on aspects that predict resilience and investment in intervention strategies for this population, as a way to promote mental health.

DESCRIPTORS: Child Adolescent. Resilience, Psychological. Violence. Risk Factors. Family Relations. Mental Health. 
${ }^{a}$ Organização Mundial da Saúde. Relatório mundial sobre a prevenção da violência 2014. São Paulo: Núcleo de Estudos da Violência da Universidade de São Paulo; 2014 [cited 2018 Mar 8]. Available from: apps.who.int/iris/ bitstream/10665/145086/ 5/9789241564793_por.pdf

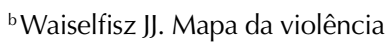
2012: crianças e adolescentes do Brasil. Rio de Janeiro: FLACSO Brasil; 2012 [cited 2018 Mar 8]. Available from: https://www. mapadaviolencia.org.br/pdf2012/ MapaViolencia2012_Criancas_e_ Adolescentes.pdf

'Azevedo MA, Guerra VNA. Violência doméstica contra crianças e adolescentes: um cenário em desconstrução. In: UNICEF Brasil. Direitos negados. Brasília (DF); 2006 [cited 2018 Mar 8]. Available from: https://www. unicef.org/brazil/pt/Cap_01.pdf

dMunist M, Santos LH,

Kotliarenco MA, Suárez Ojeda

EN, Infante F, Grotberg E. Manual

de identificación y promocion

de la resiliencia en niños y adolescentes. Washington (DC):

Organización Panamericana de la Salud; Organización Mundial de La Salud; Fundación W.K. Kellogg; Autoridad Sueca para el Desarrollo Internacional; 1998 [cited 2018 Mar 8]. Available from: http://www1.paho.org/hq/ dmdocuments/2009/Resilman.pdf

e Ministério da Saúde (BR),

Secretaria de Atenção à Saúde,

Departamento de Ações

Programáticas e Estratégicas. Linha de cuidado para a atenção integral à saúde de crianças, adolescentes e suas famílias em situação de violência: orientação para gestores e profissionais de saúde. Brasília (DF); 2012 [cited 2018 Mar 8]. (Série F. Comunicaçãao e Educação em Saúde). Available from: http://bvsms.saude.gov.br/ bvs/publicacoes/linha_cuidado criancas_familias_violencias.pdf

${ }^{\mathrm{f}}$ Munist M, Santos LH, Kotliarenco MA, Suárez Ojeda EN, Infante

F, Grotberg E. Manual de

identificación y promocion de la resiliencia en niños y adolescentes. Washington (DC): Organización Panamericana de la Salud; Organización Mundial de La Salud; Fundación W.K. Kellogg; Autoridad Sueca para el Desarrollo Internacional; 1998 [cited 2018 Mar 8]. Available from: http://www1.paho.org/hq/ dmdocuments/2009/Resilman.pdf

\section{INTRODUCTION}

Social violence, a global public health problem, directly impacts the health of individuals, regardless of social class. Along with accidents, violence is the third cause of mortality in the general population and the first among children and adolescents ${ }^{\mathrm{a}}$. In Brazil, the rate of social and community violence is very high, and more than $30 \%$ of the population lives below the poverty threshold. However, the impact of violence and emotional, cognitive and material deprivation on people's lives is still not known in its entirety, especially regarding the psychosocial and subjective aspects ${ }^{1,2}$.

The data on domestic violence are also concerning: one in four children suffers physical violence and one in five girls has suffered sexual abuse ${ }^{\mathrm{b}}$, Brazil being the fourth country with the highest child murder rate among the 92 countries analyzed ${ }^{c}$. Domestic violence against children and adolescents (DVCA) or child abuse is defined as any form of abuse, negligence, violation of rights or physical, psychological or sexual violence committed by an adult with responsibilities in relation to that growing individuald ${ }^{\mathrm{d}}$.

In Brazil, the limited structure of the services of assistance to victims of violence, in association with underreporting, makes it difficult to obtain safe incidence estimates. There are few complaints because family members, members of the community, professionals (in the fields of health, education and social assistance, among others) and the victims themselves, out of fear or for other reasons, turn a blind eye to the abusive dynamics. This phenomenon is called "conspiracy of silence"l,a,e.

The recurring assaults and abuses have serious consequences for the child or adolescent and negatively affect their physical, cognitive, emotional, and social development ${ }^{2}$. Studies ${ }^{1-3}$ indicate that experiencing situations of abuse during childhood or adolescence can be a risk factor for the development of mental health problems that, if not treated, can lead to serious consequences in adult life.

Exposure to situations of social violence at school or in the community may have a strong impact on the lives and health of children and adolescents, from physiological and psychological changes to impairment of their perspectives for the future and personal development. Some of the most commonly observed symptoms are behavioral and mood changes as well as post-traumatic stress disorder ${ }^{1}$.

Many subjects, however, manage to subdue these difficulties. Since 1950, longitudinal studies have revealed that some people, despite having been exposed to environments with multiple psychosocial risks, were able to stay emotionally healthy. A new field of study thus emerged, based on the concepts of resilience and vulnerability ${ }^{4,5, f}$. The concept of resilience has been used in various fields of knowledge. It is originally a concept of Physics, being defined as the ability of a particular body to regain its properties after having had its primary form modified by a foreign agent ${ }^{6}$. In the Humanities and Biological sciences, it is associated with the concept of vulnerability (which is also in process of construction): a set of collective and contextual aspects that can increase an individual's susceptibility to afflictions or diseases - broader than the concept of "risk", which encompassed the subject's individual issues only. Therefore, the public services' structure and the availability or lack of resources intended for the care and protection of the population becomes essential for understanding a subject's vulnerability 7, .

This study has as theoretical references the construct of resilience and the concept of safety or support network - or of child care services, even. The former is understood here as a phenomenon with a transitional character, mediated by individual capacities and associated with the subject's socio-cultural-history context, emphasizing the importance of sharing and redefining experiences. The latter refers to the group of people and systems with close and meaningful relationships with the subject, being either constant or dynamic ${ }^{8,9, g}$. 
g Ministério da Saúde (BR), Secretaria de Atenção à Saúde, Departamento de Ações Programáticas e Estratégicas. Linha de cuidado para a atenção integral à saúde de crianças, adolescentes e suas famílias em situação de violência: orientação para gestores e profissionais de saúde. Brasília (DF); 2012 [cited 2018 Mar 8]. (Série F. Comunicação e Educação em Saúde). Available from: http:// bvsms.saude.gov.br/ bvs/ publicacoes/linha_cuidado_ criancas_familias_violencias.pdf
The objective of this research was to study a group of children or adolescents who had been victims of domestic violence assisted in specialized services, and a group of students without reports of domestic violence, to learn about the predictors of resilience, the quality and perception of social support, the resources present in the family environment and the chances of them developing mental health problems.

\section{METHODS}

This is a cross-sectional, descriptive and analytical study, with 166 pairs formed by children and adolescents (9-16 years old) and their respective guardians. Of these children and adolescents, 100 were characterized as victims of domestic violence served in specialized services associated with the Centro de Referência Especializado de Assistência Social (Specialized Social Assistance Center of Reference - LICENSES) of the municipality of Campinas, state of São Paulo, constituting group 1 (G1). The remaining 66 were students of state schools located in the same regions as G1, without reports of domestic violence, constituting group 2 (G2). The children and adolescents of G1 suffered neglect of care or physical, psychological or sexual violence.

In both groups, intentional sampling was conducted ${ }^{10}$. The age group was chosen based on the instruments used and divided into four categories (9-10 years old, 11-12 years old, 13-14 years old and 15-16 years old); as second criterium, it was decided to divide the municipality into five regions (North, South, East, Southwest and Northwest), selecting an equal number of subjects per region; as last criterium, all kinds of domestic violence should have been present in each age group and region of G1. To select the subjects of G2, children or adolescents who attended schools in the same regions as G1 were sought for, so that it could be assumed that the subjects of both groups had the same level of exposure to situations of vulnerability.

As these were families in conditions of psychosocial vulnerability, many of which did not agree to participate in the research due to the theme, there was difficulty of adherence. Thus, at least 66 children or adolescents were chosen per group, 12 by region of the municipality, three by age group and one for each type of violence in G1.

Participants with previous diagnosis of neurological disease or intellectual disabilities were excluded.

\section{Instruments}

To identify the subjects' chances of developing mental health problems, the validated Brazilian version of the Strengths and Difficulties Questionnaire (SDQ) was used ${ }^{11}$. This is a widely used screening questionnaire, with positive psychometric indexes of validity and reliability in several countries, including Brazil. This instrument assesses the mental health problems of children and adolescents aged 4-16 years old, in three versions: one answered by children and adolescents aged 11-16 years old (self-application), one answered by the guardians and one answered by the teachers of subjects aged 4-16 years old. In addition, it assesses the capabilities and difficulties of these subjects, enabling their classification into three categories: normal (N), borderline (B) and abnormal (A) development. In this study, the self-application version, answered by the children and adolescents (SDQ-CA), as well as the one answered by their guardians (SDQ-G) ${ }^{11}$ were used.

To learn about the characteristics of resilience, the validated Brazilian version of the Resiliency Scales for Children and Adolescents (RSCA) of Prince-Embury ${ }^{12}$ was applied to the children and adolescents. This scale assesses individual attributes deemed as significant to the process of resilience in the 9-18 year-old age group, classifying it in: low, below average (BlA), average, above average (AbA) and high. It is composed of three scales: Scale I(SI - sense of control) assesses personal attributes such as optimism, self-efficacy and adaptability; 
Scale II (SII - relationship skills) assesses confidence, support, comfort and tolerance; and Scale III (SIII - emotional reactivity) evaluates sensitivity, recovery and damages. The psychometric parameters of the validated Brazilian version ${ }^{12}$ were satisfactory in relation to Prince-Embury's version in all three scales (Cronbach's alpha coefficients: SI - 0.83; SII -0.90 ; SIII - 0.87), indicating good internal consistency of the instrument ${ }^{12}$.

To learn about the subjects' support network, the validated Brazilian version of the Social Support Appraisals (SSA) ${ }^{13}$ was used. This instrument evaluates the perception of the social support received from family, friends, teachers and other people in the community of children and adolescents aged 9-18 years old, classifying it as low, medium and high. This is the first version of the SSA adapted to Brazilian Portuguese ${ }^{13}$, having showed appropriate psychometric parameters (alpha coefficient of the total scale: 0.79.)

A semi-structured questionnaire ${ }^{10}$ prepared by the researcher was applied to the guardians to characterize the population studied and exclude subjects who had experienced situations of domestic violence from $\mathrm{G} 2$.

The Home Environment Resources Scale (HERS) ${ }^{14}$, used with the parents, is a Brazilian instrument used to learn about the resources of the family environment: supervision and organization of routines, opportunities for interaction with the parents, presence of resources in the physical environment and characterization of the family. The HERS ${ }^{14}$ showed internal consistency, with appropriate psychometric parameters (alpha coefficient of the total scale: 0.74 ).

\section{Procedures}

Data were collected from March 2014 to February 2016. The interviews were carried out simultaneously with the pairs (with the consent of the children or adolescents and their guardians) by two psychologists with experience in applying the instruments. In G1, 50\% occurred on the families' visitation day at the services; due to the high absenteeism, some were also carried out at their houses $(26 \%)$ and at the school or socio-educational center frequented by the children and adolescents (24\%). In G2, the interviews were carried out with the pairs at the schools that agreed to participate in the research.

This study was approved by the Research Ethics Committee of the School of Medical Sciences of Universidade Estadual de Campinas (Process 371,078), by the Municipal Secretariat of Citizenship and Social Inclusion (municipality of Campinas) and by the State Secretariat of Education (Regional Executive Boards of Education of Campinas).

\section{Data Analysis}

The data were processed using the SPSS software version $16.0^{15}$, and presented in tables containing the absolute and relative frequencies.

To assess the association between the variables, the chi-square test or the Fisher-FreemanHalton test were employed. In addition, the odds ratio (OR) was determined, the non-fitted OR having been calculated via univariate logistic regression (ENTER method). In this case, the dependent variable resilience, with its low, $\mathrm{BlA}$, medium, $\mathrm{AbA}$ and high categories, was reduced to only two categories: low (low/BlA) and adequate (medium/ABa/high).

The fitted OR values were determined via multivariate logistic regression (Backward Stepwise "Wald" method), with $p$-value $=0.05$ for inclusion and $p$-value $=0.10$ for exclusion. All predicting variables with $p$-value $<0.20$ were selected for the univariate analysis.

\section{RESULTS}

Of the 166 children and adolescents in the study, 89 (53.6\%) were female. All children and adolescents were studied, 100 in G1 and 66 in G2. In G1, 25 children of the total 100 belonged 
to each age group (9-10; 11-12; 13-14; 15-16 years), whereas in G2, from 15 to 18 of the total 66 belonged to each of them; as for region, in G1, 20 of the total 100 belonged to each region (North, South, East, Northwest and Southwest) and in G2, from 12 to 14 of the total 66 belonged to each of them.

In this study, $63 \%$ of the children or adolescents (G1) suffered more than one form of violence, psychological violence being the most frequent ( $82 \%$ ), followed by neglect or abandonment (58\%), sexual violence (26\%) and physical violence (23\%). The main aggressors were the parents, father and mother (50.9\%) or only one of them (30\%).

The distribution, with differences between the groups in relation to socioeconomic status and number of people per residence, is presented in Table 1.

As for the prevalence of resilience, G1 featured $72 \%$ of adequate and $28 \%$ of low resilience in SI, $92 \%$ of adequate and $8 \%$ of low resilience in SII, and $87 \%$ of adequate and $13 \%$ of low resilience in SIII. G2 featured $74.2 \%$ of adequate and $25.8 \%$ of low resilience in SI, $89.4 \%$ of adequate and $10.6 \%$ of low resilience in SII, and $98.5 \%$ of adequate and $1.5 \%$ of low resilience in SIII.

The prevalence of low resilience measured by the three resilience scales and distributed by group, socioeconomic conditions, number of people per residence, sex, age, SSA and RAF in the univariate analysis are presented in Tables 2, 3 and 4.

Table 1. Socioeconomic conditions and number of inhabitants per household by group.

\begin{tabular}{|c|c|c|c|c|c|c|c|}
\hline \multirow{3}{*}{ Socioeconomic conditions and family infrastructure } & \multicolumn{4}{|c|}{ Group } & \multirow{2}{*}{\multicolumn{2}{|c|}{ Total }} & \multirow{3}{*}{ p } \\
\hline & \multicolumn{2}{|c|}{ G1 $(n=100)$} & \multicolumn{2}{|c|}{ G2 $(n=66)$} & & & \\
\hline & $\mathbf{n}$ & $\%$ & $\mathbf{n}$ & $\%$ & $\mathbf{n}$ & $\%$ & \\
\hline Guardian's labor situation & & & & & & & $0.012^{\mathrm{a}}$ \\
\hline Formal job with labor rights & 34 & 34.0 & 36 & 54.6 & 70 & 42.2 & \\
\hline Steady job without labor rights & 9 & 9.0 & 2 & 3.0 & 11 & 6.6 & \\
\hline Regular self-employment & 14 & 14.0 & 14 & 21.2 & 29 & 17.5 & \\
\hline Irregular self-employment & 10 & 10.0 & 3 & 4.5 & 12 & 7.2 & \\
\hline Unemployed or retired & 33 & 33.0 & 11 & 16.7 & 44 & 26.5 & \\
\hline Total household income (minimum wages) ${ }^{c}$ & & & & & & & $<0.001^{\mathrm{a}}$ \\
\hline Less than 1 & 34 & 34.0 & 4 & 6.0 & 38 & 22.9 & \\
\hline Between 1 and 2 & 40 & 40.0 & 13 & 19.7 & 53 & 31.9 & \\
\hline Between 2 and 3 & 19 & 19.0 & 18 & 27.3 & 37 & 22.3 & \\
\hline More than 3 & 7 & 7.0 & 31 & 47.0 & 38 & 22.9 & \\
\hline Social benefit & & & & & & & $0.002^{\mathrm{a}}$ \\
\hline Yes & 59 & 59.0 & 23 & 34.8 & 82 & 49.4 & \\
\hline No & 41 & 41.0 & 43 & 65.2 & 84 & 50.6 & \\
\hline Number of people living in the house & & & & & & & $0.113^{\mathrm{a}}$ \\
\hline From 1 to 4 & 42 & 42.0 & 36 & 54.5 & 78 & 47.0 & \\
\hline Five or more & 58 & 58.0 & 30 & 45.5 & 88 & 53.0 & \\
\hline Guardian's education level & 98 & 100.0 & 63 & 100 & $161^{\mathrm{d}}$ & 100 & $<0.001^{\mathrm{b}}$ \\
\hline Illiterate & 1 & 1.0 & 3 & 4.8 & 4 & 2.5 & \\
\hline Elementary School I & 35 & 35.7 & 11 & 17.5 & 46 & 28.6 & \\
\hline Elementary School II & 38 & 38.8 & 13 & 20.6 & 51 & 31.7 & \\
\hline High School & 20 & 20.4 & 30 & 47.6 & 50 & 31.1 & \\
\hline Higher Education & 4 & 4.1 & 6 & 9.5 & 10 & 6.2 & \\
\hline
\end{tabular}

p: probability; G1: group 1; G2: group 2

a Probability estimated by the Chi-square test.

${ }^{b}$ Probability estimated by the Fisher-Freeman-Halton Test.

c Including social benefits.

${ }^{d}$ Five (5) guardians who did not provide this information were not included in the analysis.

Values with statistical significance are presented in bold. 
Table 2. Distribution of resilience evaluated by Scale I (sense of control) in relation to socioeconomic status, number of inhabitants per household, group, sex, age, SSA and HERS.

\begin{tabular}{|c|c|c|c|c|c|c|}
\hline \multirow{2}{*}{ Variable } & \multicolumn{2}{|c|}{ Low+BIA } & \multirow{2}{*}{ Total } & \multirow[b]{2}{*}{ p } & \multirow{2}{*}{ OR } & \multirow{2}{*}{$95 \% \mathrm{Cl}$} \\
\hline & $\mathbf{n}$ & $\%$ & & & & \\
\hline Group & & & & 0.750 & & \\
\hline G1 & 28 & 28.0 & 100 & & 1.12 & $0.55-2.27$ \\
\hline G2 & 17 & 25.8 & 66 & & 1.00 & \\
\hline Guardian's labor situation & & & & 0.911 & & \\
\hline Unemployed or retired & 13 & 29.5 & 44 & & 0.91 & $0.40-2.08$ \\
\hline Irregular self-employment & 4 & 30.8 & 13 & & 0.97 & $0.18-2.95$ \\
\hline Regular self-employment & 6 & 21.4 & 28 & & 0.60 & $0.21-1.67$ \\
\hline Steady job without labor rights & 0 & 0 & 11 & & 0.00 & a \\
\hline Formal job with labor rights & 22 & 31.4 & 70 & & 1.00 & \\
\hline Income (minimum wages) & & & & 0.591 & & \\
\hline Less than 1 & 8 & 21.1 & 38 & & 0.75 & $0.26-2.16$ \\
\hline Between 1 and 2 & 14 & 26.4 & 53 & & 1.01 & $0.39-2.59$ \\
\hline Between 2 and 3 & 13 & 35.1 & 37 & & 1.52 & $0.56-4.08$ \\
\hline More than 3 & 10 & 26.3 & 38 & & 1.00 & \\
\hline Social benefit & & & & 0.261 & & \\
\hline No & 26 & 31.0 & 84 & & 1.49 & $0.74-2.97$ \\
\hline Yes & 19 & 23.2 & 82 & & 1.00 & \\
\hline Number of people living in the house & & & & 0.273 & & \\
\hline Five or more & 27 & 30.7 & 88 & & 1.48 & $0.74-2.96$ \\
\hline From 1 to 4 & 18 & 23.1 & 78 & & 1.00 & \\
\hline Guardian's education level & & & & 0.876 & & \\
\hline Illiterate & 1 & 25.0 & 4 & & 1.33 & $0.09-20.71$ \\
\hline Elementary School I & 12 & 26.1 & 46 & & 1.41 & $0.26-7.60$ \\
\hline Elementary School II & 12 & 23.5 & 51 & & 1.23 & $0.23-6.60$ \\
\hline High School & 16 & 32.0 & 50 & & 1.88 & $0.36-9.90$ \\
\hline Higher Education & 2 & 20.0 & 10 & & 1.00 & \\
\hline Sex & & & & 0.693 & & \\
\hline Female & 23 & 25.8 & 89 & & 0.87 & $0.44-1.73$ \\
\hline Male & 22 & 28.6 & 77 & & 1.00 & \\
\hline Age (years) & & & & 0.937 & & \\
\hline 9 to 10 & 12 & 30.0 & 40 & & 1.11 & $0.43-2.86$ \\
\hline 11 to 12 & 11 & 26.8 & 41 & & 0.95 & $0.36-2.47$ \\
\hline 13 to 14 & 10 & 23.8 & 42 & & 0.81 & $0.30-2.14$ \\
\hline 15 to 16 & 12 & 27.9 & 43 & & 1.00 & \\
\hline SSA-Family & & & & 0.019 & & \\
\hline Low & 12 & 42.9 & 28 & & 20.25 & $2.40-170.68$ \\
\hline Mean & 32 & 29.1 & 110 & & 11.08 & $1.44-85.01$ \\
\hline High & 1 & 3.6 & 28 & & 1.00 & \\
\hline SSA-Friends & & & & 0.001 & & \\
\hline Low & 11 & 55.0 & 20 & & 7.74 & $2.51-23.89$ \\
\hline Mean & 25 & 31.3 & 80 & & 2.88 & $1.23-6.72$ \\
\hline High & 9 & 13.6 & 66 & & 1.00 & \\
\hline SSA-Teacher & & & & $<0.001$ & & \\
\hline Low & 6 & 37.5 & 16 & & 5.47 & $1.57-19.07$ \\
\hline Mean & 31 & 44.9 & 69 & & 7.44 & $3.12-17.78$ \\
\hline High & 8 & 9.9 & 81 & & 1.00 & \\
\hline SSA-Other & & & & $<0.001$ & & \\
\hline Low & 12 & 57.1 & 21 & & 31.33 & $5.97-164.48$ \\
\hline Mean & 31 & 32.3 & 96 & & 11.21 & $2.56-49.15$ \\
\hline High & 2 & 4.1 & 49 & & 1.00 & \\
\hline SSA-Total & & & & 0.003 & & \\
\hline Low & 12 & 46.2 & 26 & & 41.14 & $4.91-344.52$ \\
\hline Mean & 32 & 35.2 & 91 & & 26.03 & $3.43-197.53$ \\
\hline High & 1 & 2.0 & 49 & & 1.00 & \\
\hline HERS-Routine & - & - & - & 0.603 & 1.01 & $0.99-1.03$ \\
\hline HERS-Interaction & - & - & - & 0.931 & 1.00 & $0.98-1.02$ \\
\hline HERS-Resources & - & - & - & 0.755 & 1.00 & $0.98-1.02$ \\
\hline HERS-Total & - & - & - & 0.745 & 1.00 & $0.98-1.03$ \\
\hline
\end{tabular}

BIA: below average; p: probability estimated by the Wald test; G1: Group 1; G2: Group 2; SSA: Social Support Appraisals; HERS: Home Environment Resources Scale

a Undetermined.

Values with statistical significance are presented in bold. 
Table 3. Distribution of resilience evaluated by Scale II (relationship skills) in relation to socioeconomic status, number of inhabitants per household, group, sex, age, SSA and HERS.

\begin{tabular}{|c|c|c|c|c|c|c|}
\hline \multirow{2}{*}{ Variable } & \multicolumn{2}{|c|}{ Low+BIA } & \multirow{2}{*}{ Total } & \multirow{2}{*}{$\mathbf{p}$} & \multirow{2}{*}{ OR } & \multirow{2}{*}{$95 \% \mathrm{Cl}$} \\
\hline & $\mathbf{n}$ & $\%$ & & & & \\
\hline Group & & & & 0.568 & & \\
\hline G1 & 8 & 8.0 & 100 & & 0.73 & $0.25-2.13$ \\
\hline G2 & 7 & 10.6 & 66 & & 1.00 & \\
\hline \multicolumn{7}{|l|}{ Guardian's labor situation } \\
\hline Unemployed or retired & 3 & 6.8 & 44 & & 0.57 & $0.14-2.26$ \\
\hline Irregular self-employment & 0 & 0 & 12 & & 0.00 & a \\
\hline Regular self-employment & 4 & 14.3 & 28 & 0.896 & 1.29 & $0.36-4.69$ \\
\hline Steady job without labor rights & 0 & 0 & 11 & & 0.00 & a \\
\hline Formal job with labor rights & 8 & 11.4 & 70 & & 1.00 & \\
\hline \multicolumn{7}{|l|}{ Income (minimum wages) } \\
\hline Less than 1 & 2 & 5.3 & 38 & & 0.37 & $0.07-2.02$ \\
\hline Between 1 and 2 & 4 & 7.5 & 53 & 0.646 & 0.54 & $0.13-2.16$ \\
\hline Between 2 and 3 & 4 & 10.8 & 37 & & 0.80 & $0.20-3.25$ \\
\hline More than 3 & 5 & 13.2 & 38 & & 1.00 & \\
\hline \multicolumn{7}{|l|}{ Social benefit } \\
\hline No & 7 & 8.3 & 84 & 0.749 & 0.84 & $0.29-2.44$ \\
\hline Yes & 8 & 9.8 & 82 & & 1.00 & \\
\hline \multicolumn{7}{|l|}{ Number of people living in the house } \\
\hline Five or more & 11 & 12.5 & 88 & 0.109 & 2.64 & $0.81-8.67$ \\
\hline From 1 to 4 & 4 & 5.1 & 78 & & 1.00 & \\
\hline \multicolumn{7}{|l|}{ Guardian's education level } \\
\hline Illiterate & 0 & 0 & 4 & & 0.00 & a \\
\hline Elementary School I & 5 & 10.9 & 46 & & 1.10 & $0.11-10.57$ \\
\hline Elementary School II & 4 & 7.8 & 51 & 0.991 & 0.77 & $0.08-7.67$ \\
\hline High School & 5 & 10.0 & 50 & & 1.00 & $0.10-9.61$ \\
\hline Higher Education & 1 & 10.0 & 10 & & 1.00 & \\
\hline Sex & & & & 0.573 & & \\
\hline Female & 7 & 7.9 & 89 & & 0.74 & $0.25-2.13$ \\
\hline Male & 8 & 10.4 & 77 & & 1.00 & \\
\hline Age (years) & & & & 0.139 & & \\
\hline 9 to 10 & 1 & 2.5 & 40 & & 0.19 & $0.02-1.75$ \\
\hline 11 to 12 & 7 & 17.1 & 41 & & 1.56 & $0.45-5.39$ \\
\hline 13 to 14 & 2 & 4.8 & 42 & & 0.38 & $0.07-2.08$ \\
\hline 15 to 16 & 5 & 11.6 & 43 & & 1.00 & \\
\hline SSA-Family & & & & 0.153 & & \\
\hline Low & 6 & 21.4 & 28 & & a & a \\
\hline Mean & 9 & 8.2 & 110 & & a & a \\
\hline High & 0 & 0 & 28 & & 1.00 & \\
\hline SSA-Friends & & & & $<0.001$ & & \\
\hline Low & 9 & 45.0 & 20 & & 12.68 & $3.32-48.48$ \\
\hline Mean & 2 & 2.5 & 80 & & 0.40 & $0.07-2.24$ \\
\hline High & 4 & 6.1 & 66 & & 1.00 & \\
\hline SSA-Teacher & & & & 0.001 & & \\
\hline Low & 6 & 37.5 & 16 & & 15.60 & $3.36-72.36$ \\
\hline Mean & 6 & 8.7 & 69 & & 2.48 & $0.60-10.30$ \\
\hline High & 3 & 3.7 & 81 & & 1.00 & \\
\hline SSA-Other & & & & 0.001 & & \\
\hline Low & 7 & 33.3 & 21 & & 24.00 & $2.72-211.93$ \\
\hline Mean & 7 & 7.3 & 96 & & 3.78 & $0.45-31.59$ \\
\hline High & 1 & 2.0 & 49 & & 1.00 & \\
\hline SSA-Total & & & & $<0.001$ & & \\
\hline Low & 9 & 34.6 & 26 & & 25.41 & 2.99-215.72 \\
\hline Mean & 5 & 5.5 & 91 & & 2.79 & $0.32-24.59$ \\
\hline High & 1 & 2.0 & 49 & & 1.00 & \\
\hline HERS-Routine & - & - & - & 0.805 & 1.00 & $0.97-1.04$ \\
\hline HERS-Interaction & - & - & - & 0.162 & 0.98 & $0.95-1.01$ \\
\hline HERS-Resources & - & - & - & 0.401 & 1.01 & $0.98-1.05$ \\
\hline HERS-Total & - & - & - & 0.965 & 1.00 & $0.96-1.01$ \\
\hline
\end{tabular}

BIA: below average; p: probability estimated by the Wald test; G1: Group 1; G2: Group 2; SSA: Social Support Appraisals; HERS: Home Environment Resources Scale

andetermined.

Values with statistical significance are presented in bold. 
Table 4. Distribution of resilience evaluated by Scale III (emotional reactivity) in relation to socioeconomic status, number of inhabitants per household, group, sex, age, SSA and HERS.

\begin{tabular}{|c|c|c|c|c|c|c|}
\hline \multirow{2}{*}{ Variable } & \multicolumn{2}{|c|}{ Low+BIA } & \multirow{2}{*}{ Total } & \multirow{2}{*}{$\mathbf{p}$} & \multirow{2}{*}{ OR } & \multirow{2}{*}{$95 \% \mathrm{Cl}$} \\
\hline & $\mathbf{n}$ & $\%$ & & & & \\
\hline Group & & & & 0.030 & & \\
\hline G1 & 13 & 13.0 & 100 & & 9.71 & $1.24-76.14$ \\
\hline G2 & 1 & 1.5 & 66 & & 1.00 & \\
\hline \multicolumn{7}{|l|}{ Guardian's labor situation } \\
\hline Unemployed or retired & 5 & 11.4 & 44 & & 2.12 & $0.54-8.35$ \\
\hline Irregular self-employment & 2 & 15.4 & 13 & 0.746 & 3.00 & $0.48-18.39$ \\
\hline Regular self-employment & 2 & 7.1 & 28 & & 1.27 & $0.22-7.36$ \\
\hline Steady job without labor rights & 1 & 9.1 & 11 & & 1.65 & $0.17-16.29$ \\
\hline Formal job with labor rights & 4 & 5.7 & 70 & & 1.00 & \\
\hline \multicolumn{7}{|l|}{ Income (minimum wages) } \\
\hline Less than 1 & 3 & 7.9 & 38 & & 1.54 & $0.24-9.80$ \\
\hline Between 1 and 2 & 8 & 15.1 & 53 & 0.216 & 3.20 & $0.64-16.01$ \\
\hline Between 2 and 3 & 1 & 2.7 & 37 & & 0.50 & $0.04-5.76$ \\
\hline More than 3 & 2 & 5.3 & 38 & & 1.00 & \\
\hline \multicolumn{7}{|l|}{ Social benefit } \\
\hline No & 5 & 6.0 & 84 & 0.251 & 0.51 & $0.16-1.60$ \\
\hline Yes & 9 & 11.0 & 82 & & 1.00 & \\
\hline \multicolumn{7}{|l|}{ Number of people living in the house } \\
\hline Five or more & 7 & 8.0 & 88 & 0.814 & 0.88 & $0.29-2.62$ \\
\hline From 1 to 4 & 7 & 9.0 & 78 & & 1.00 & \\
\hline \multicolumn{7}{|l|}{ Guardian's education level } \\
\hline Illiterate & 1 & 25.0 & 4 & & 3.00 & $0.14-64.26$ \\
\hline Elementary School I & 2 & 4.3 & 46 & & 0.41 & $0.03-5.01$ \\
\hline Elementary School II & 6 & 11.8 & 51 & 0.511 & 1.20 & $0.13-11.21$ \\
\hline High School & 3 & 6.0 & 50 & & 0.57 & $0.05-6.16$ \\
\hline Higher Education & 1 & 10.0 & 10 & & 1.00 & \\
\hline Sex & & & & 0.015 & & \\
\hline Female & 13 & 14.6 & 89 & & 13.00 & $1.66-101.86$ \\
\hline Male & 1 & 1.3 & 77 & & 1.00 & \\
\hline Age (years) & & & & 0.131 & & \\
\hline 9 to 10 & 3 & 7.5 & 40 & & 0.31 & $0.08-1.23$ \\
\hline 11 to 12 & 0 & 0.0 & 41 & & a & a \\
\hline 13 to 14 & 2 & 4.8 & 42 & & 0.19 & $0.04-0.93$ \\
\hline 15 to 16 & 9 & 20.9 & 43 & & 1.00 & \\
\hline SSA-Family & & & & 0.001 & & \\
\hline Low & 8 & 28.6 & 28 & & 10.80 & $1.25-93.44$ \\
\hline Mean & 5 & 4.5 & 110 & & 1.29 & $0.14-11.47$ \\
\hline High & 1 & 3.6 & 28 & & 1.00 & \\
\hline SSA-Friends & & & & 0.676 & & \\
\hline Low & 2 & 10.0 & 20 & & 1.72 & $0.29-10.18$ \\
\hline Mean & 8 & 10.0 & 80 & & 1.72 & $0.49-6.00$ \\
\hline High & 4 & 6.1 & 66 & & 1.00 & \\
\hline SSA-Teacher & & & & 0.008 & & \\
\hline Low & 5 & 31.3 & 16 & & 8.75 & $2.03-37.63$ \\
\hline Mean & 5 & 7.2 & 69 & & 1.50 & $0.39-5.84$ \\
\hline High & 4 & 4.9 & 81 & & 1.00 & \\
\hline SSA-Other & & & & 0.148 & & \\
\hline Low & 4 & 19.0 & 21 & & 5.53 & $0.93-32.98$ \\
\hline Mean & 8 & 8.3 & 96 & & 2.14 & $0.44-10.47$ \\
\hline High & 2 & 4.1 & 49 & & 1.00 & \\
\hline SSA-Total & & & & 0.024 & & \\
\hline Low & 6 & 23.1 & 26 & & 7.05 & $1.31-37.97$ \\
\hline Mean & 6 & 6.6 & 91 & & 1.66 & $0.32-8.55$ \\
\hline High & 2 & 4.1 & 49 & & 1.00 & \\
\hline HERS-Routine & - & - & - & $<0.001$ & 0.94 & $0.90-0.97$ \\
\hline HERS-Interaction & - & - & - & 0.002 & 0.95 & $0.92-0.98$ \\
\hline HERS-Resources & - & - & - & 0.321 & 0.98 & $0.95-1.02$ \\
\hline HERS-Total & - & - & - & 0.001 & 0.93 & $0.89-0.97$ \\
\hline
\end{tabular}

BIA: below average; p: probability estimated by the Wald test; G1: Group 1; G2: Group 2; SSA: Social Support Appraisals; HERS: Home Environment Resources Scale

a Undetermined.

Values with statistical significance are presented in bold. 
Table 5. Final multivariate model of low resilience (low/BIA) in the three Scales for sex, SSA and HERS.

\begin{tabular}{|c|c|c|c|c|}
\hline Resiliency questionnaire & $\begin{array}{c}\text { Variable } \\
\text { independent }\end{array}$ & p & Adjusted OR & $95 \% \mathrm{Cl}$ \\
\hline & SSA-Teacher & 0.010 & & \\
\hline Scale I & Low & & 2.84 & $0.74-10.85$ \\
\hline \multirow[t]{3}{*}{ (sense of control) } & Mean & & 4.19 & $1.66-10.57$ \\
\hline & High & & 1.00 & \\
\hline & SSA-Other & 0.012 & & \\
\hline Scale I & Low & & 14.08 & $2.47-80.36$ \\
\hline \multirow[t]{3}{*}{ (sense of control) } & Mean & & 6.81 & $1.49-31.18$ \\
\hline & High & & 1.00 & \\
\hline & SSA-Other & 0.033 & & \\
\hline Scale II & Low & & 17.45 & $1.26-242.29$ \\
\hline (relationship & Mean & & 1.00 & \\
\hline \multirow[t]{2}{*}{ skills) } & High & & 1.00 & \\
\hline & Sex & 0.021 & & \\
\hline Scale III & Female & & 15.49 & $1.50-160.10$ \\
\hline \multirow[t]{2}{*}{ (emotional reactivity) } & Male & & 1.00 & \\
\hline & SSA-Teacher & 0.019 & & \\
\hline Scale III & Low & & 37.16 & 2.89-478.43 \\
\hline \multirow[t]{2}{*}{ (emotional reactivity) } & Mean & & 1.88 & $0.36-9.69$ \\
\hline & High & & 1.00 & \\
\hline $\begin{array}{l}\text { Scale III } \\
\text { (emotional reactivity) }\end{array}$ & HERS-Routine & 0.005 & 0.94 & $0.90-0.98$ \\
\hline
\end{tabular}

BIA: below average; p: probability estimated by the Wald test; SSA: Social Support Appraisals; HERS: Home Environment Resources Scale.

Values with statistical significance are presented in bold.

As in the analysis of resilience no other differences between G1 and G2 were found, it was decided to group them for studying the factors that could interfere in the construction of this skill.

After the multivariate analysis, only variables SSA-teacher and SSA-other remained in SI; only SSA-other remained in SII; and only sex, SSA-teacher and HERS-routine remained in SIII. In all of them, a low perception of social support was associated with a higher chance of low resilience. As for emotional reactivity (SIII), girls were 15.49 times more likely to show low resilience than boys (Table 5).

SDQ-C/A was applied to 126 subjects (75 from G1 and 51 from G2), while SDQ-G was applied to all 166. The SDQ-C/A analysis showed that, in G1,52\% (39/75) could be placed in the abnormal (27/75) or borderline (12/75) categories, while in G2, this occurred in $33.3 \%$ (17/51) of the subjects (abnormal: 11; borderline: 6$)(\mathrm{p}=0.112)$.

As for SDQ-R, 64\% (64/100) of G1 could be placed in categories A (41/100) and L (23/100), while in G2, this occurred in 37.9\% (25/66) of the subjects (abnormal: 20/66; borderline: $5 / 66)(p=0.002)$.

In addition, the subjects of G1 and G2 with low resilience in SI of the RSCA were 4.9 times more likely to develop mental health problems (A) in SDQ-C/A [OR $=4.90$ (95\%CI 1.66-14.44) $(p=0.008)]$. In the other scales, no association between low resilience and mental health problems was observed.

\section{DISCUSSION}

Despite advances in the research on resilience, they are recent, with controversies and disagreements as to the definitions, concepts and research methods, which complicates the comparison of data ${ }^{14}$. Current research with populations of children and adolescents in 
situations of social vulnerability carried out in Latin American countries showed prevalence rates corresponding to $71.7 \%$ and $65.8 \%$ resilience, using different instruments ${ }^{16,17}$.

In the results of this study, the children and adolescents who had been victims of violence (G1), although exposed to traumatic situations, showed a prevalence of adequate resilience corresponding to $72 \%$ (SI), 92\% (SII) and $87 \%$ (SIII), and of low resilience corresponding to $28 \%$ (SI), 8\% (SII) and 13\% (SIII) (Tables 2, 3 and 4). These data are similar to those of other studies with subjects in situations of social vulnerability ${ }^{16,17}$ and also to those of G2, with a small difference in SIII (1.5\% in the low category) (Table 4).

Another research ${ }^{18}$ performed with a group of institutionalized children exposed to interparental violence, compared to a group of subjects without violations of rights, found levels of resiliency, coping and social competence that were considered adequate (using other instruments). There were no differences between the groups, except for higher frequency of coping strategies in the first group and for these having been perceived by the children as more effective. Acting out-type strategies (situations of physical and verbal aggression) were also more frequent in the first group and the children recognize them as more effective, compared to unexposed children, despite them being ineffective strategies.

In the multivariate analysis (Table 5), low perception of social support (other people in the community and teachers) was also associated with a greater chance of low resilience.

Subjects with low perception of support by other people in the community had more chances of low resilience in the personal attributes of optimism, adaptability and selfefficacy (SI) and in relationship skills (SII) (Table 5). Another study examined the influence of people considered significant in the community on the construction of aspects that predict resilience in children and adolescents who have been victims of domestic violence; according to this study, these figures play a moderating role in the subjects' cognitive ability and home stability ${ }^{19}$. The functions performed by role models (even more distant ones, like people in the community) and by the social support network are fundamental protective factors in the construction of resilience ${ }^{20}$.

The school and the teachers were identified as major sources of protection for the subjects of this study (Table 5). It was found that children and adolescents with smaller perception of support from the teacher had higher chances of low resilience in the personal attributes of optimism, self-efficacy and adaptability (SI) and in emotional reactivity (SIII). The perception of support from the teacher is crucial, and the school is as important source of support, generating feelings of greater safety, especially for children/adolescents in situation of vulnerability and with weakened role models in their families. Thus, distancing in teacherstudent relationships may be considered a risk factor ${ }^{21}$.

The literature indicates the family as the main source of social support ${ }^{20}$, and family stability and social relations as important predictors of a more adaptive and resilient emotional competence ${ }^{22}$. Surprisingly, as opposed to these researches, the multivariate analysis of this study did not identify it as predictive of resilience, neither as a vulnerability factor in any of the RSCA scales ${ }^{12}$. The hypothesis is that the conjunction of so many concurrent problems in these families hinders the perception of this support by the subjects of the study, which does not mean to say the role of support they can exercise should be ruled out.

It was found that families in situation of domestic violence (G1) had higher socioeconomic vulnerability compared to those in G2, but these aspects are not associated with the predictors of resilience. Precarious socioeconomic conditions can aggravate the situations of violence and also the risk of problems in the psycho-emotional development of children and adolescents ${ }^{23,24}$.

It was found through the $\mathrm{RAF}^{14}$ that children and adolescents who had rules or routine in their lives showed lower chances of low resilience in emotional reactivity (SIII) (Table 5). Parents with negligent characteristics cannot establish a routine for their children, which 
hampers the construction of resilience in general. Therefore, the function of social support through the establishment of rules or routines for the children, in which the family has a fundamental role, generates feelings of security and helps the subjects process their emotions, avoiding the onset of mental disorders ${ }^{9,12,20}$.

The girls of this study had higher chances of low resilience in emotional reactivity (SIII). This index shows the ability to manage or regulate emotions, to maintain one's balance in stressful situations ${ }^{12}$. It is assumed, from the discussions about gender issues, that girls of both groups may be experiencing situations of higher risk, which increase their emotional limitations or make them react in self-defense. Having been victim of sexual abuse in childhood and being raised by guardians with anti-social behavior or some kind of dependency on psychoactive substances are indicated as risk factors for conduct disorders among girls ${ }^{18,25}$.

The literature shows that the prevalence of mental disorders in children and adolescents varies between $10 \%$ and $20 \%{ }^{26}$.

The prevalence of chances of mental health problems found in G1 using both versions of the SDQ were quite high (52\% in SDQ-C/A and 64\% in SDQ-G). In another research ${ }^{3}$, these authors found similar data using the SDQ, with the prevalence of chances of mental health problems in children and adolescents who had been victims of domestic violence having corresponded to $65.6 \%$, compared to the general population.

However, the rates presented by G2 were also high (33.3\% in SDQ-C and 37.9\% in SDQ-G), compared to the average of the population. These rates can be associated with the fact that the children and adolescents of G2 had also been exposed to possible situations of social or community violence, poor health and housing conditions, economic and cultural difficulties, low educational level of the guardians, among other situations of vulnerability. These factors may affect the subjects' global and emotional development, causing these high rates of emotional symptoms ${ }^{1,20}$.

A research ${ }^{27}$ that used the Child Behavior Checklist observed a sharp increase in internalizing and externalizing mental health problems, especially in children whose mothers have low education level and in families with greater socioeconomic vulnerability, corroborating studies conducted in other countries.

Domestic violence against children and adolescents was shown to be a risk factor for greater chance of mental health problems in the subjects studied, based on the evaluation of SDQ-G ( $p=0.002$ ), including in $\mathrm{G} 2$. This result is relevant for studies in the field of children's mental health ${ }^{2,3,28}$.

In addition, it was found that the children and adolescents from both groups with low resilience in SI (sense of control), which assesses individual strategies to deal with stressful events (optimism, self-efficacy and adaptability ${ }^{12}$ ) were 4.9 times more likely to develop mental health problems in SDQ-C/A. This indicates an association between less resilient subjects and higher prevalence of emotional symptoms. The hypothesis is that children and adolescents, regardless of the group in which they were inserted, experience the consequences of a frail external social support, as it assists in the construction of resilience and in the protection against the early onset of emotional disorders. Social support, allied to healthy educational practices, helps moderating the negative effects of situations of vulnerability and protects the children against precarious care, helplessness, violence and isolation ${ }^{20,21}$.

The high absenteeism in the interviews in both groups, due to the social vulnerability of the population as a whole and to the theme chosen, was a limitation of the study. However, the importance of carrying out studies in the field of domestic and social or community violence should be emphasized, despite the difficulties of access to this population, for the construction of more effective public service policies. 
The resilience rates shown by the subjects of this study (Tables 2, 3 and 4) indicate good perspectives for the future, though they are neither uniform nor static - an individual can be resilient in some respects and not in others, or even show resiliency in different ways in the various stages of $\operatorname{life}^{22}$. At the same time, they expressed suffering through important emotional symptoms, those subjected to domestic violence having shown more serious problems. Specialized services may be exerting a role in the construction of predictors of resilience for the children and adolescents in G1; however, because they experienced traumatic situations, they showed important emotional problems ${ }^{1-3,20}$. In relation to G2, the chance of mental health problems may be associated also with the possible exposure to social and community violence?

Therefore, reflecting about the aspects that influence the construction of resilience and situations of violence may contribute so that mental disorders are avoided or do not become chronic $^{29}$. In addition, the importance of investing in early intervention strategies ${ }^{7,29}$ aimed at promoting the quality of the relationship between children and adults is emphasized. The presence of role models with adequate conditions for offering social support can assist in the protection of their mental health and strengthen their resilience, which is dynamic and can change according to the intrinsic characteristics of the subject or the social relationships experienced.

\section{CONCLUSIONS}

Violence may have increased the chance of development of mental health problems, domestic violence being an aggravating factor. In this study, it was identified that girls had higher chances of low resilience in emotional reactivity, i.e., difficulties to cope and recover emotionally from a situation of vulnerability. Children and adolescents with low resilience in relation to emotional reactivity were more likely to develop mental health problems.

The absence of perception of social support from the teacher and other people in the community of the children and adolescents was also identified as vulnerability or risk factor, being associated with low resilience. On the other hand, the presence of routine or rules established by the guardians was considered a protective factor.

The perception of adequate social or emotional support can be an important protective factor and facilitate the development of resiliency. Investments in psychosocial work and the strengthening of effective actions based on the concept of a care network for families in situation of violence can be strategies for the development of predictors of resilience.

There is need for research on aspects that predict resilience and investment in intervention strategies for this population, as a way to promote mental health.

\section{REFERENCES}

1. Assis SG, Avanci JQ, Pesce RP, Ximenes LF. Situação de crianças e adolescentes brasileiros em relação à saúde mental e à violência. Cienc Saude Coletiva. 2009;14(2):349-361. https://doi.org/10.1590/S1413-81232009000200005

2. Cicchetti D, Doyle C. Child maltreatment, attachment and psychopathology: mediating relations. World Psychiatry. 2016;15(2):89-90. https://doi.org/10.1002/wps.20337

3. Hildebrand NA, Celeri EHRV, Morcillo AM, Zanolli ML. Violência doméstica e risco para problemas de saúde mental em crianças e adolescentes. Psicol Reflex Crít. 2015;28(2):213-21. https://doi.org/10.1590/1678-7153.201528201

4. Rutter M. Psychosocial resilience and protective mechanisms. Am J Orthopsychiatry. 1987;57(3):316-31. https://doi.org/10.1111/j.1939-0025.1987.tb03541.x

5. Werner EE. High-risk children in young adulthood: a longitudinal study from birth to 32 years. Am J Orthopsychiatry. 1989;59(1):72-81. https://doi.org/10.1111/j.1939-0025.1989.tb01636.x 
6. Timoshenko S. History of strength of materials: with a brief account of the history of theory of elasticity and theory of structures. New York: McGraw-Hill; 1953.

7. Muñoz Sánchez AI, Bertolozzi MR. Pode o conceito de vulnerabilidade apoiar a construção do conhecimento em Saúde Coletiva? Cienc Saude Coletiva. 2007;12(2):319-24. https://doi.org/10.1590/S1413-81232007000200007

8. Reppold CT, Mayer JC, Almeida LS, Hutz CS. Avaliação da resiliência: controvérsia em torno do uso das escalas. Psicol Reflex Crit. 2012;25(2):248-55. https://doi.org/10.1590/S0102-79722012000200006

9. Noronha MGRCS, Cardoso PS, Moraes TNP, Centa ML. Resiliência: nova perspectiva na promoção da saúde da família? Cienc Saude Coletiva. 2009;14(2):497-506. https://doi.org/10.1590/S1413-81232009000200018

10. Minayo MCS. O desafio do conhecimento: pesquisa qualitativa em saúde. 11.ed. São Paulo: Hucitec; 2008.

11. Goodman R, Meltzer H, Bailey V. The strengths and difficulties questionnaire: a pilot study on the validity of the self-report version. Eur Child Adolesc Psychiatry. 1998;7(3):125-30. https://doi.org/10.1080/08039480801984032

12. Barbosa RJ. Tradução e validação da escala de resiliência para crianças e adolescentes de Sandra Prince-Embury [dissertação]. São Paulo: Pontifícia Universidade Católica de São PauloPUC/SP; 2008.

13. Squassoni CE, Matsukura TS. Adaptação transcultural da versão portuguesa do social support appraisals para o Brasil. Psicol Reflex Crit. 2014;27(1):71-80. https://doi.org/10.1590/S0102-79722014000100009

14. Marturano EM. O inventário de recursos do ambiente familiar. Psicol Reflex Crit. 2006;19(3):498-506. https://doi.org/10.1590/S0102-79722006000300019

15. SPSS Inc. Statistical Package for Social Sciences: version 16.0. Chicago: IBM.

16. Huaire Inacio EJ. Prevalencia de resiliencia y autoestima sobre el rendimiento escolar en estudiantes de instituciones educativas de Ate Vitarte, Lima. Apunt Cienc Soc. 2014;4(2):202-9. https://doi.org/10.18259/acs.2014023.

17. Ulloque-Caamaño L, Monterrosa-Castro A, Arteta-Acosta C. Prevalencia de baja autoestima y nivel de resiliencia bajo, en gestantes adolescentes de poblaciones del caribe colombiano. Rev Chil Obstet. 2015;80(6):462-74. https://doi.org/10.4067/S0717-75262015000600006

18. Moreira ACF. Resiliência e coping: a exposição a violência interparental enquanto experiência traumática [dissertação]. Porto (POR): Faculdade de Psicologia e de Ciência da Educação da Universidade do Porto; 2012.

19. DuMont KA, Widom CS, Czaja SJ. Predictors of resilience in abused and neglected children grown-up: the role of individual and neighborhood characteristics. Child Abuse Negl. 2007;31(3):255-74. https://doi.org/10.1016/j.chiabu.2005.11.015

20. Squassoni CE, Matsukura TS, Panúncio-Pinto MP. Apoio social e desenvolvimento socioemocional infantojuvenil. Rev Ter Ocup. 2014;25(1):27-35. https://doi.org/10.11606/issn.2238-6149.v25i1p27-35

21. Afifi TO, Macmillan HL. Resilience following child maltreatment: a review of protective factors. Can J Psychiatry. 2011;56(5):266-72. https://doi.org/10.1177/070674371105600505

22. Alves CF, Dell'Aglio DD. Percepção de apoio social de adolescentes de escolas públicas. Rev Psicol IMED. 2015;7(2):89-98. https://doi.org/10.18256/2175-5027/psico-imed.v7n2p89-98

23. Abreu DP, Viñas F, Casas F, Montserrat C, González-Carrasco M, Alcantara SC. Estressores psicossociais, senso de comunidade e bem-estar subjetivo em crianças e adolescentes de zonas urbanas e rurais do Nordeste do Brasil. Cad Saude Publica. 2016;32(9):e00126815. https://doi.lorg/10.1590/0102-311X00126815

24. Poletto M, Koller SH, Dell'Aglio DD. Eventos estressores em crianças e adolescentes em situação de vulnerabilidade social de Porto Alegre. Cienc Saude Coletiva. 2009;14(2):455-66. http://doi.org/10.1590/S1413-81232009000200014

25. Pinto RMF, Micheletti FABO, Bernardes LM, Fernandes JMPA, Monteiro GV, Silva MLN, et al. Condição feminina de mulheres chefes de família em situação de vulnerabilidade socialdaptação transcultural da versão portuguesa do social support appraisals para o Brasil. Serv Soc Soc. 2011;(105):167-79. https://doi.org/10.1590/S0101-66282011000100010 
26. Polanczyk GV, Salum GA, Sugaya LS, Caye A, Rohde LA. Annual research review: a metaanalysis of the worldwide prevalence of mental disorders in children and adolescents. J Child Psychol Psychiatry. 2015;56(3):345-65. https://doi.org/10.1111/jcpp.12381

27. Matijasevich A, Murray E, Stein A, Anselmi L, Menezes AM, Santos IS, et al. Increase in child behavior problems among urban Brazilian 4-year olds: 1993 and 2004 Pelotas birth cohorts. J Child Psychol Psychiatry. 2014;55(10):1125-34. https://doi.org/10.1111/jcpp.12236

28. Pires TO, Silva CMFP, Assis SG. Ambiente familiar e transtorno de déficit de atenção e hiperatividade. Rev Saude Publica. 2012;46(4):624-33. https://doi.org/10.1590/S0034-89102012005000043

29. Hernández-Holguín DM, Sánchez IC, Páez E, Montoya-Vásquez EM. El desarrollo personal de los jóvenes de Medellín, Colombia: más allá de las conductas de riesgo y de resiliencia. Cad Saude Publica. 2016;32(11):e00103614. https://doi.or/10.1590/0102-311x00103614

Funding: Coordenação de Aperfeiçoamento de Pessoal de Nível Superior (CAPES - doctorate fellowship Process 01-P-4525/2013).

Authors' Contribution: Study design and planning: NAH, EHRVC, MLZ. Data collection: NAH. Data analysis and interpretation: NAH, EHRVC, AMM, MLZ. Drafting or proofreading of the manuscript: NAH, EHRVC, AMM, MLZ. All authors approved the final version of the manuscript and take full responsibility for its contents.

Conflict of Interest: The authors declare no conflict of interest. 